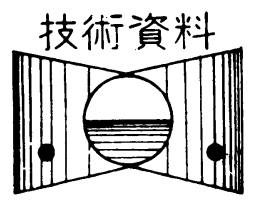

\title{
ハイリースキュードプロペラの 翼応力実測解析*
}

\section{穂森繁弘 ${ }^{* *}$. 馬場宣裕 ${ }^{* *}$. 佐々木康夫 ${ }^{* *}$}

\author{
Full-Scale Stress Measurements and Analyses \\ on a Highly Skewed Propeller
}

By Shigehiro Homori, Nobuhiro Baba, Yasuo Sasaki

In recent years, the highly skewed propellers tend to be used for the prevention of the growth of ship vibration and noise. On the other hand, however, the blade strength of the highly skewed propeller under the ship operating condition has not been measured up to the present time, in spite of the need for the judgement on the blade strength. Therefore, the authors measured the blade stresses of the highly skewed propeller which was fitted on a Pure Car Carrier.

After analyzing the measured data, it has been found that the maximum principal stress induced on the pressure surface of the blade at the point of $0.4 \mathrm{R}$ with $90 \%$ camber length from leading edge became maximum in value when the propeller chip clearance became minimum.

Furthermore, the measured principal stress mode within one revolution has been compared with the calculated result by the FEM analysis and the both have a similar tendency in the mode.

\section{1. 緒言}

近年, 船尾振動及び騷音の軽減を目的として, Highly Skewed Propeller(以下, HSP 上略記する)の採用が 検討され，今後，実船に数多く使用されることが予想さ れる. HSPの性能及び船体振動の起振力としてのサー フェスフォースとシャフトフォースに関する実験研究は 比較的数多く行われているが ${ }^{1,2,3)}$, 実船に装着された HSPの実㗢中のプロペラ翼に発生する応力に関しては， 必ずしあ実態か把握されていないようである. 周知のと おりHSPのプロペラ翼応力に関しては，その形状から 曲げとねじりが複雑に作用する応力分布を呈する事が指 摘され，水槽実験における船尾伴流中の模型プロペラ翼 の応力計測例が発表されている 供試模型プロペラの設計条件に相違があるにもかかわら ず, Conventional Propeller (以下, CP 之略記する)に おける応力分布とは異なり, 全ての場合について翼根部 から $0.5 \mathrm{R}$ 付近の翼後緑部において応力が大きな值を示 すととが指摘されている．筆者らは，乙れを実船で確認 するために比較的大形の HSPを装着した自動車専用船 の試運転時に, 総合実船計測の一環として, プロペラ翼 応力及び軸力(トルク, スラスト)の計測を行ったので,

\footnotetext{
* 原稿受付 昭和 57 年 11 月 1 日

昭和 57 年秋季学術講演 (昭和 57 年 10 月 27 日)

** 正会員 日本海事協会技術研究所（三鷹市新川 6-20-1）
}

測定結果の一部について，その概要を紹介する．又， HSPの翼強度を検討する際, プロペラ翼の応力分布を 把握するととが不可欠であるととから，筆者らが開発し た実働時のプロペラ翼応力解析プログラムNKPBSAP (NK Propeller Blade Stress Analysis Program) $に$ よる解析結果と計測結果との比較検討を行ったので，そ の概要についても併せて報告する.

\section{2. 実船計測概要}

\section{1 実験船の主要目 実船計測を行った船は,} 自動車専用船で，表 1 亿船体，機関及びプロペラの主要 目を示す.

\section{2 計測方法 プロペラ翼のひずみゲージ貼付位}

表 1 Principal paticulars of ship

\begin{tabular}{|c|c|c|}
\hline 7 & \multicolumn{2}{|c|}{ Particulars } \\
\hline \multirow[b]{2}{*}{ Hull } & Type & Aft. Engine \\
\hline & $\begin{array}{l}\text { LxBxD } \\
\text { Full Load Draft } \\
\text { Block Coefficient } \\
\text { Gross Tonnage } \\
\text { Sea Speed }\end{array}$ & $\begin{array}{l}166 \mathrm{~m} \times 27 \mathrm{~m} \times 11.9 \mathrm{~m} \\
8.220 \mathrm{~m} \\
0.5269 \\
11.000 \mathrm{GT} \\
17.4 \mathrm{Knot}\end{array}$ \\
\hline \multirow[b]{2}{*}{ Main Engine } & Type & 2Cycle S.A. Sup.Cha. D. \\
\hline & $\begin{array}{l}\text { No. of Cyl. } x \\
\text { Borex Stroke } \\
\text { Max. Cont.Rating } \\
\end{array}$ & $\begin{array}{l}8 \times 550 \mathrm{~mm} \times 1380 \mathrm{~mm} \\
12000 \mathrm{PS} \times 155 \mathrm{r} \mathrm{pm}\end{array}$ \\
\hline \multirow[b]{2}{*}{ Propeller } & Type & Highly Skewed \\
\hline & $\begin{array}{l}\text { No. of Bladex } \\
\text { Dia.xPitch } \\
\text { Skew Angle } \\
\text { Material }\end{array}$ & $\begin{array}{l}5 \times 4700 \mathrm{~mm} \times 4137 \mathrm{~mm}(0.7 \mathrm{R}) \\
45.80 \mathrm{eg} . \\
\mathrm{KAIBC3}\end{array}$ \\
\hline
\end{tabular}




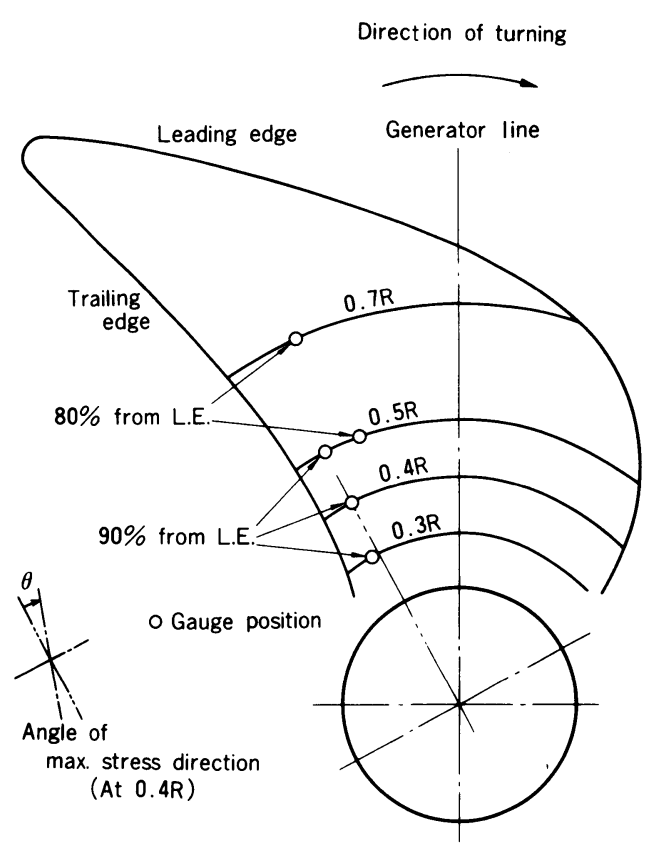

図 1 ひずみゲージ貼付位置

置は, 四 1 亿示す通りで, 前進面の $0.3 \mathrm{R}, 0.4 \mathrm{R}, 0.5 \mathrm{R}$, 後進面の $0.5 \mathrm{R} ， 0.7 \mathrm{R}$ の計 5 箇所に 3 軸ひずみゲージを 貼付した.ひずみゲージの貼付後の防水処理及びリード線 の翼面上の固定防水処理は，何れす SR-126 部会で用 いられた方法を採用した ${ }^{6)}$. リード線の機関室への取り 込み方法は，まず図 2 に示すプロペラキャップのグリス 注入口から翼面に貼付したアクティブゲージのリード線 を取り入れ，キャップ内のプロペラ軸端面に貼付したダ ミーゲージとでブリッジを構成した後，中空軸としたプ ロペラ軸の中心孔を通して，プロペラ軸フランジ端面に 設けた溝状のスリットからリード線を取り出す方法とし た. 又，トルク及びスラストは，中間軸にひずみゲージ を貼付し，ねじり及び軸方向ひずみを検出し，プロペラ 翼からのひずみ検出と共に FMテレメータにより計測し

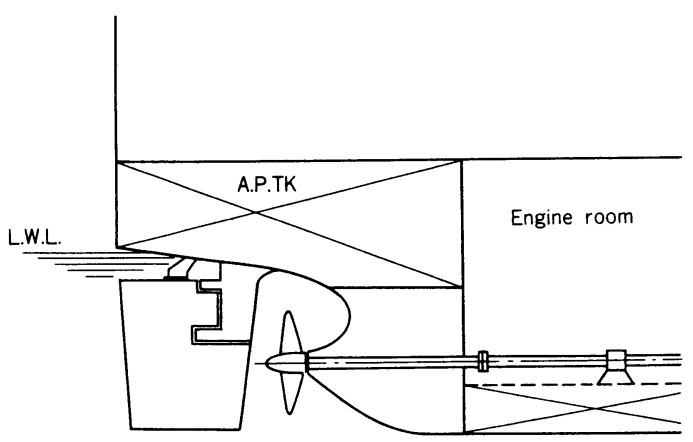

Profile of aft part

因 2 船尾構造概略
た. テレメータ方式による計測方法は, 図 2 に示す中間 軸の円周上に，FMテレメータの発信器とバッテリ及び 発信アンテナを取り付け，一方，軸の回りを囲む固定受 信アンテナからのリード線を計測室に設置した FM受信 器に導くことによりゲージ出力を受信する方法とした. なお，計測データは，アナログ式データレコーダに収録 し、データ解析の基準とするために，中間軸に 1 回転 1 パルスを発する回転マークを設け，計測データと共にデ ータレコーダに同時収録した。

計測は $36 \mathrm{rpm}$ から $159 \mathrm{rpm}$ までの間を $2 \sim 5$ 回転おき に漸次回転数をあげ，それぞれ所定の回転数において回 転が整定した状態で行った。

計測は 3 日間にわたって行ったが, 計測中の海象状況 はきわめて秪やかであり，風力階級は 3 以下で，ローリ ング, ピッチング共にほとんどなく, 理想的な気象・海 象状態であった.

\section{3. 計測結果と考察}

3.1 トルク変動 計測されたトルク変動と, プロ ペラ翼応力変動との対応関係は現在解析中であるが，乙 てではトルク変動の回転次数比解析結果について述べる.

図 3 亿中間軸における軸回転数に対するねじり応力変 動分布とねじり応力から換算した軸馬力を示す. 四から分 るように中間軸におりるトルク変動の主成分は， 3 次， 4 次, 5 次, 8 次及び 11 次であり, 主軸系のねじり振動 計算による固有振動数が 1 節で $320.7 \mathrm{rpm}, 2$ 節で 1375.6 $\mathrm{rpm}$ であることから，3 次，4 次，5次，8 次は 1 節振動

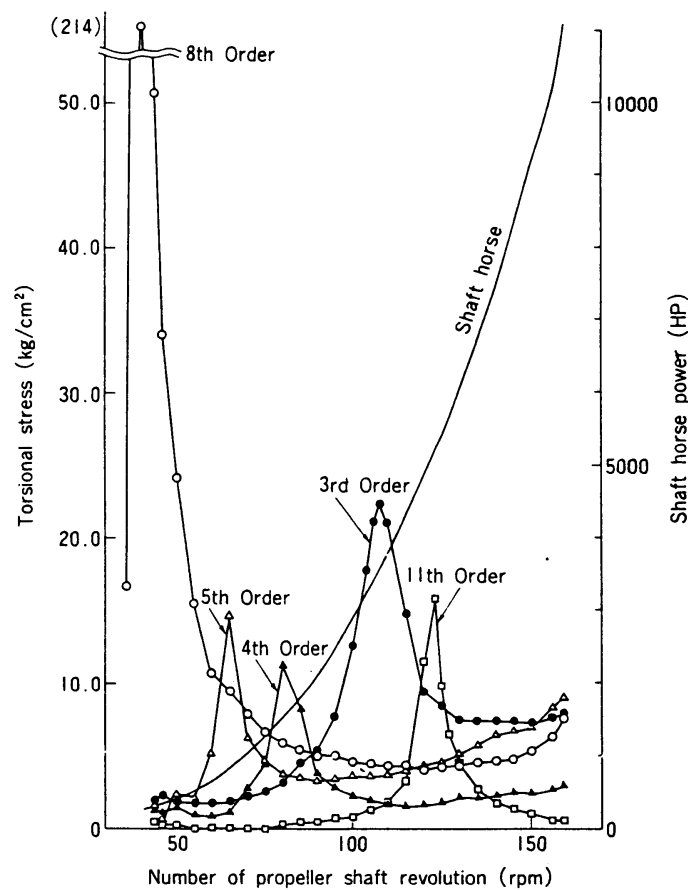

困 3 中間軸におけるねじり応力変動分布之軸馬力 
で, 11 次が 2 節振動であることが分かる. 又, 本船の搭 載主機が 8 シリンダであることから，8次のねじり応力 成分が, 他の次数成分より極端に大きな值となっている. 回転が上昇するに従い，5次の変動成分が漸増し，150 $\mathrm{rpm}$ を越えた範囲でその值が大きくなる傾向にある. これは，本船に装備されたプロペラが 5 翼であるととか ら, 低回転域ではトルク変動がねじり振動により大きく 影響を受けるが, 高回転域ではプロペラによる影響が漸 増してくるものと推定される. この傾向はCPを装備し た船でのプロペラ翼応力, 軸力の実測例であ報告されて いる.なお，罒中に示す中間軸における軸出力は，ほぼ 基本設計計画どおりであった.

3.2 プロペラ 图 4 は, 翼前進面で $0.4 \mathrm{R}$ の前縁から $90 \%$ 翼弦長位置での CSOに相当する 156 $\mathrm{rpm}$ における代表的な応力波形について, プロペラ 2 回 転間の最大主応力の大きさと, その方向の変化を示した あのである. 図の横軸は, プロペラ翼が、上側に位置す る時に, GL (Generator Line) が船体の中心線となす 角度をプロペラ回転方向を正として表わしたあのである. 縦軸は最大主応力値とその方向を示す.

最大主応力の方向は, 図 1 に示す計測点における半径 方向基準線からの角度が後縁側に向う方向を負としてい る.

図の最大主応力波形から, プロペラ翼が上側の位置, 即ち横軸の $0^{\circ}$ の位置から $180^{\circ}$ の位置まで回転して行く 間，約 $45^{\circ}$ および $160^{\circ}$ の近傍でそれぞれ $3.62 \mathrm{~kg} / \mathrm{mm}^{2}$ 及び $3.3 \mathrm{~kg} / \mathrm{mm}^{2}$ の極值を持ち, 前者は回転に対し急激 に変化しているが, 後者は緩やかに変化する特徽を示し ている. CPの応力計測例 ${ }^{n, 7,8)}$ であ, 極值を生じる位置 は異なるが, 類似の応力波形が示されている. しかし， CPの応力波形亡較へ，本計測結果では，二つの極値の 差が小さく，プロペラの 1 回転における応力分布が平均 化する傾向にある. これはプロペラが回転する際，スキ ュー形状に起因して, 各半径の翼素が時間的なずれを生 じながら伴流中を通過することに原因するすのと思われ る. 次に, 最大主応力值が最も大きくなる位置は, 既述 のように翼が船の中心線を通過後, GL が中心線と約 $45^{\circ}$ の時である. HSPのスキュー角度が $45.8^{\circ}$ であることか

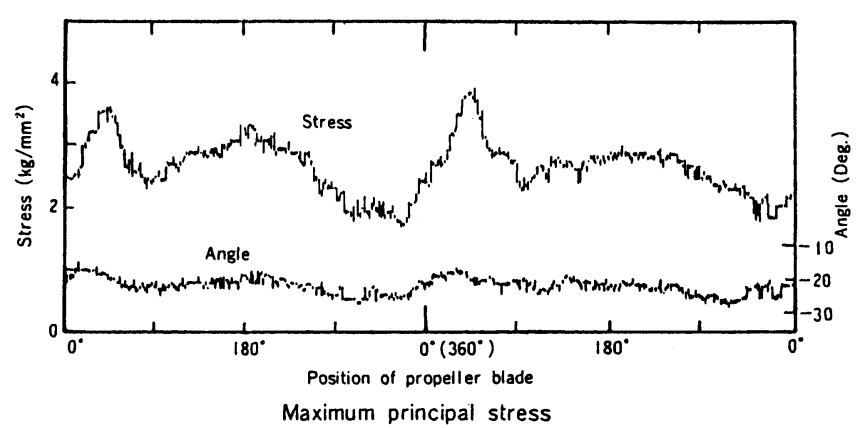

図 $40.4 \mathrm{R}$ ，前縁より $90 \%$ 翼弦長位置における 最大主応力 (実測值)
ら最大主応力が最も大きくなるのは，プロペラチップク リアランスが最小となる近傍であると言える. 次に, 最 大主応力の方向であるが, すべて負の值となっており， 図 1 に示す計測点における半径方向基準線より常に後縁 側を向いている.このような傾向は，定性的には，該部 での曲げに対し，スキュー形状に起因するねじりが影響 しているためと思われる.

\section{4. 計測値と有限要素モデルによる 解析値の比較}

プロペラ翼応力解析プログラムシステムNKPBSAP を用いて，HSPの応力解析を行った. 図 5 に示すよう に, プロペラ翼を翼弦方向に 11 分割, 半径方向に 14 分 割する要素分割として解析を行った．荷重計算に用いた 伴流分布は模型試験による本船のバラスト状態のもので あり，笹島の方法で，実船の伴流分布に修正したあので ある. 解析時の幾何学的境界条件は, $0.194 \mathrm{R}$ 翼弦上の 節点を完全固定とした.なおプログラムの概要について は付録を参照されたい.

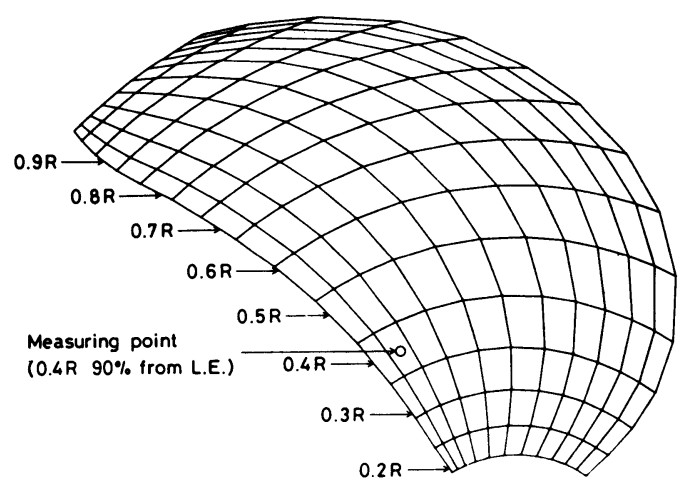

困 5 プロペラ翼要素分割

図 6 から図 9 に解析結果の一例を示す. 図 6 は $0.4 \mathrm{R}$ の応力計測点に対応する位置の要素で, プロペラ 1 回転 における応力変化を示したものである. 図から最大主応 力値は約 $3 \mathrm{~kg} / \mathrm{mm}^{2}$, 変動応力振幅值は約 $0.9 \mathrm{~kg} / \mathrm{mm}^{2}$, 1 回転間における平均応力は約 $2.3 \mathrm{~kg} / \mathrm{mm}^{2}$ となってい る.

又, プロペラ位置が $0^{\circ}$ から $180^{\circ}$ の間で 二つの極值を持ち, $0^{\circ}$ 近傍の極值が最大值 となる波形の傾向は実船計測結果之一致し ているが, 最大応力値と変動応力振幅值及 び応力波形自体は，図 4 亿示す実船計測値 之隔たりがある. この隔たりの原因につい ては，次のような事に主因があるものと思 われる.すなわち，荷重計算に用いた非定 常揚力面理論は，CPを対象としたもので あり，理論展開に際して，スキュー形状を 考慮していないため，翼面の圧力分布が実 


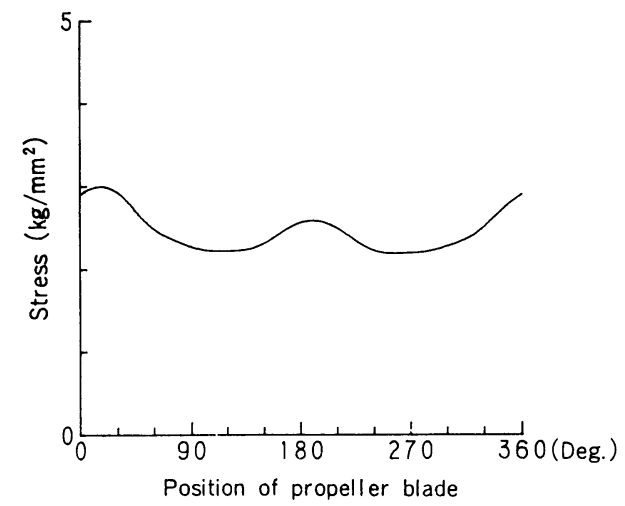

図 $60.4 \mathrm{R}$ ，前縁より $90 \%$ 翼弦長位置における 最大主応力 (計算值)

際の分布と異なっており，乙れを節点荷重に変換して解 析した事により，計測値と異なる結果となったあのと思 われる.

次に図 7 , 図 8 及び図 9 に有限要素解析により得られ た翼前進面上の最大主応力分布, 最大主応力の等高線, 翼の変位を示す. 図 7 に示すように最大主応力は, 翼根 部の最大翼厚点近傍で最大值を示しており, 又, 翼根部 から $0.8 \mathrm{R}$ 付近の範囲の翼後縁部においてかなり大きな 値となっている他, $0.85 \mathrm{R}$ 前後の翼前縁部においても， 最大主応力が大きくなっているが，乙のような傾向は， スキュー量が極端に少ないCPでは生じておらず市，HSP

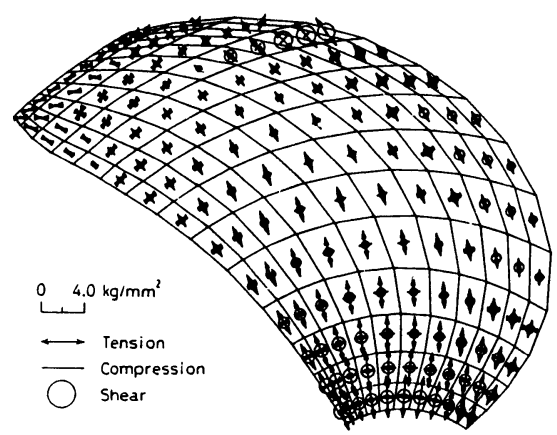

困 7 翼前進面の最大主応力分布

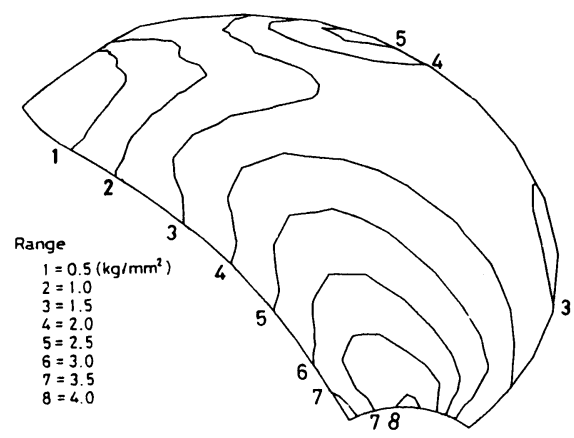

図 8 翼前進面の最大主応力の等高線
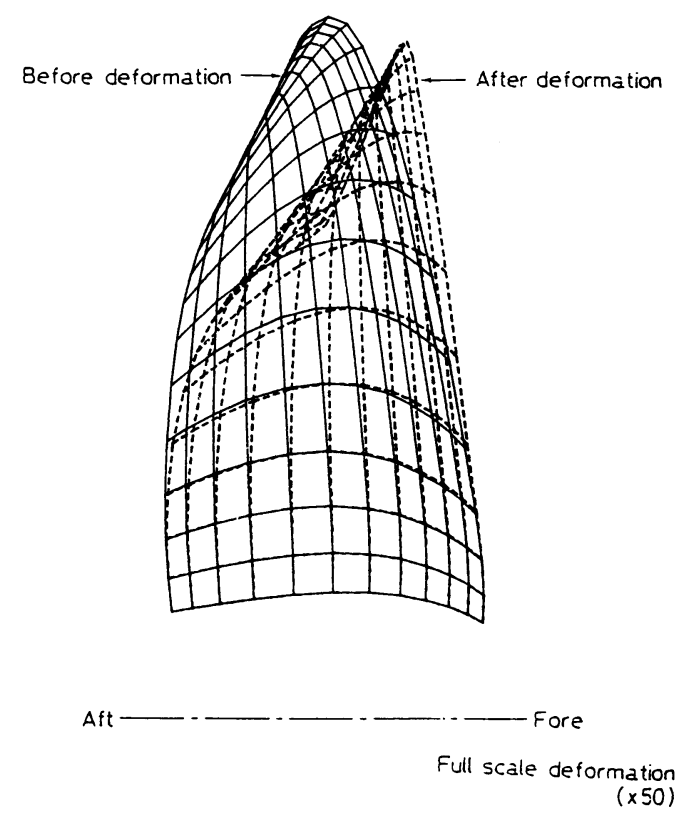

図 9 翼の変形モード

特有のスキュー形状に起因する曲げねじりによる影響で あると推定される.

図 8は最大主応力值を等高線で示したものであり， $\mathrm{CP}$ の場合之異なり, 翼後縁部であかなり大きな值とな っており，かつ翼前縁部でも $0.85 \mathrm{R}$ 付近で最大主応力值 が増大している状態が明瞭にうかがえる. このように， 従来の CP と対比して, 最大主応力の分布形状が異なる ので，スキュー形状及びそれにより誘起される応力状態 によっては，翼の曲げねじりに起因し，座屈を生じる恐 れああるので, スキュー形状に応じて, 翼の座屈強度の 検討あ必要になってくるものと思われる.

図 9 はプロペラ実働時の変形を, プロペラ回転面に平 行な方向に三次元透視図で示したものである. 図から翼 がやや札じられる傾向にある事が分かる.

\section{5. 結言}

HSPの実働時のプロペラ翼応力を把握するために， HSPを装着した自動車専用船の試運転時にプロペラ翼 応力を計測し, 応力変動の解析を行った結果, 次の事が 分かった。

プロペラ翼前進面上の $0.4 \mathrm{R} て ゙$ 翼前縁より $90 \%$ 翼弦長 の位置に打ける応力計測結果から。

（1）プロペラ 1 回転間に, 計測位置で最大主応力が, 最も大きな值となるのは，チップクリアランスが最む小 さくなる位置，すなわち $\mathrm{GL}$ が船体中心之約 $45^{\circ}$ をす 近傍であった。

（2）計測点における最大主応力方向は，プロペラ 1 回 転中, 常に翼後縁側に向いている.

（3）プロペラ 1 回転間の応力波形は, CP と対比して, 
応力分布が平滑化する傾向にある．乙れはスキュー形状 に起因し, 各半径の翼素が位相差を持って伴流中を通過 することによるあのと考えられる.

（4）有限要素法による応力解析結果加, 各半径の翼 素に注目すると，翼根部加 $0.8 \mathrm{R}$ 付近の範囲の翼後縁 部で, 最大主応力が大きな值を示す. 又, $0.85 \mathrm{R}$ 付近の 翼前縁部であ最大主応力值が増大している。

現在, 軸力 (トルク, スラスト)と翼応力との関係を解 析中であるが、スキュー形状を考慮に入れた翼荷重を用 いた有限要素法による応力解析結果が求められた時点で, 報告の幾会を得たい. 又, 本船の航洋時における総合実 船計測あ予定されているので, それらの実測結果が得ら れた時点で, 航洋時のプロペラ翼応力の評価についても 検討する予定である.

本実船計測に際し，多大のご協力を頂いた神原汽船， 常石造船及び神戸製鋼所の関係各位に深堪の謝意を表す ると共に, 静的翼応力計測試験結果を提供して下さった ナカシマプロペラの関係各位に厚く御礼申し上げます. 又, プロペラ翼へのひずみゲージ貼付方法に関し，種々 ご教示頂いた船舶技術研究所機関性能部長植田氏, 三菱 重工業(株)長崎研究所推進性能研究室長谷林氏及び同研 究室主務笹島氏に厚く御礼申し上げます.

なお，本実船計測に際し，困難な作業に尽力された当 技術研究所機関研究室の凌志浩氏, 住吉茂雄氏, 城戸口 秀典氏に感謝致します.

\section{文献}

1）凌 志浩・佐々木康夫；ハイリィスキュードプロペラと標 準プロペラにより誘起されるプロペラ起振力および船体振 動に関する実船比較試験, 日本造船学会論文集, 第 151 号 (1982).

2）中島 稔・菅野博志・久保博尚・板谷芳樹; ハイリィスキ ュードプロペラの系統的模型試験および実船実験, 日本舶 用機関学会誌, 第 17 巻第 1 号(1982).

3) T. V. Daniel and J. D. Francis; Highly Skewed Propeller for San Clemente Class Ore/Bulk/Oil Carrier Design Considerations, Model and Full Scale Evaluation, presented at the First Ship Technology and Research Symposium SNAME (1975)

4）千葉規胤・中村直人；ハイリィスキュードプロペラの実験 的研究，三菱重工技法，Vol.18，No.1(1981).

5）山崎正三郎・高橋通雄·早見信博·萭 忠志·藤本敏雄; Highly Skewed Propellerの研究(第 3 報)、日本造船学 会論文集, 第 150 号(1981).

6）大型プロペラの翼強度に関する研究; 第 126 研究部会 (1973).

7）植田靖夫 - 前橋正雄 - 塩出敬二郎 - 竹沢節雄 - 高井元弘; プロペラ翼応力の実測試験, 日本舶用機関学会誌, 第 8 巻 第 9 号 (1973).

8）渡辺恭二・稗田伸行・笹島孝夫 ·松尾 慥 ; コンテナ船箱 根丸による就航中のプロペラ翼応力計測, 日本舶用機関学 会誌, 第 9 巻第 12 号 (1974).

9) Terji S $\phi$ ntvedt; Propeller blade stress, application of finite element methods, Computer \& Structures,
Pergamon Press Vol. 4 (1974)

\section{付録}

プロペラ翼応力解析プログラム NKPBSAP (NK Propeller Blade Stress Analysis Program)の概要

本解析プログラムシステムは, プロペラ実働時の翼応 力分布を正確に推定する目的で開発されたすので, 汎用 構造解析プログラムSAP 6 の薄肉シェル要素を使用し, 入力データ作成のプリプロセッサ, 解析結果を種々の形 で出力するポストプロセッサから成る専用プログラムシ ステムである. 解析には薄肉シェル要素を用いているこ 亡から,

（1）ねじりを含んだ曲げを比較的良く評価できる.

（2）要素分割に際し, 翼素形状を考慮した剛性評価を 行っていることから節点数, 要素数が比較的少なくて闵 む.

などの特徴がある. 薄肉シェル要素によるプロペラ翼 の解析モデル化 ${ }^{9)}$ の妥当性をみるために, HSPの翼に 点荷重を加え, 発生する翼応力を計測した静的荷重試験 ${ }^{2)}$ の結果亡, 本プログラムシステムによる解析結果の比較 を行ったが, 図A 1 に示すように主応力值及びその方向 とあによい一致を示している. したがって採用した薄肉 シェル要素による解析は信頼性の高いあのと考えてよい.

なお, 解析に際しプロペラ実働時に翼に加わる荷重は, 非定常揚力面理論を用いて圧力分布を算出し, これを力 学的平衡条件を満すように節点荷重に換算したものを用 いている.

\section{〔質 疑 応 答〕}

\section{質問者 日立造船技術研究所 斎藤年正}

〔閴〕FMテレメータを用いてスラスト計測を行っ ているようですが, スラスト計測はトルク計測に比べ, ひずみ量も小さく，計測上困難な場合が多い.

今回の計測で, 何か特別な手段を講じられたのであれ ば, 书聞かせ願いたい。

〔回答〕長期間にわたるスラスト計測は別として，実 験期間が短期間(例えば公試運転時等)であれば, 基本的 には次の諸点に留意することで，大きな計測誤差は生じ ないと考えております．まず，使用するひずみゲージは 一般に使用されている120オームより大きな抵抗值のあ のを使用する. 軸回転中に遠心力で結線部分に抵抗変化 を生じないよう，結線部分等を完全に固定する. 受信ア ンテナから受信器までの配線は外部からのノイズに影響 されないよう適当な線を使用する.なお，以上はテレメ 一タが, 温度、遠心力等の影響をほとんど受けないあの を使用するととを前提にしております.

質問者 日立造船 (株)造機基本設計部 浅野泰男

〔䓄間〕1. 本講演でで教示されたのはプロペラ正転時 


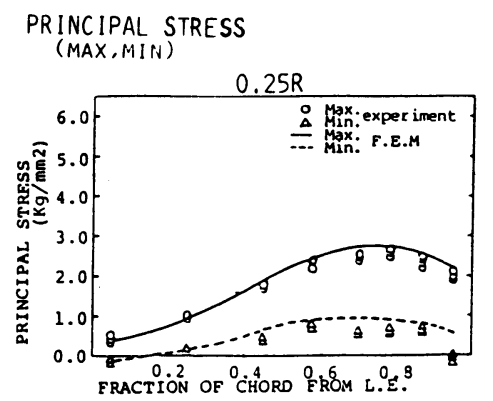

DIRECTION OF MAX PRINCIPAL STRESS
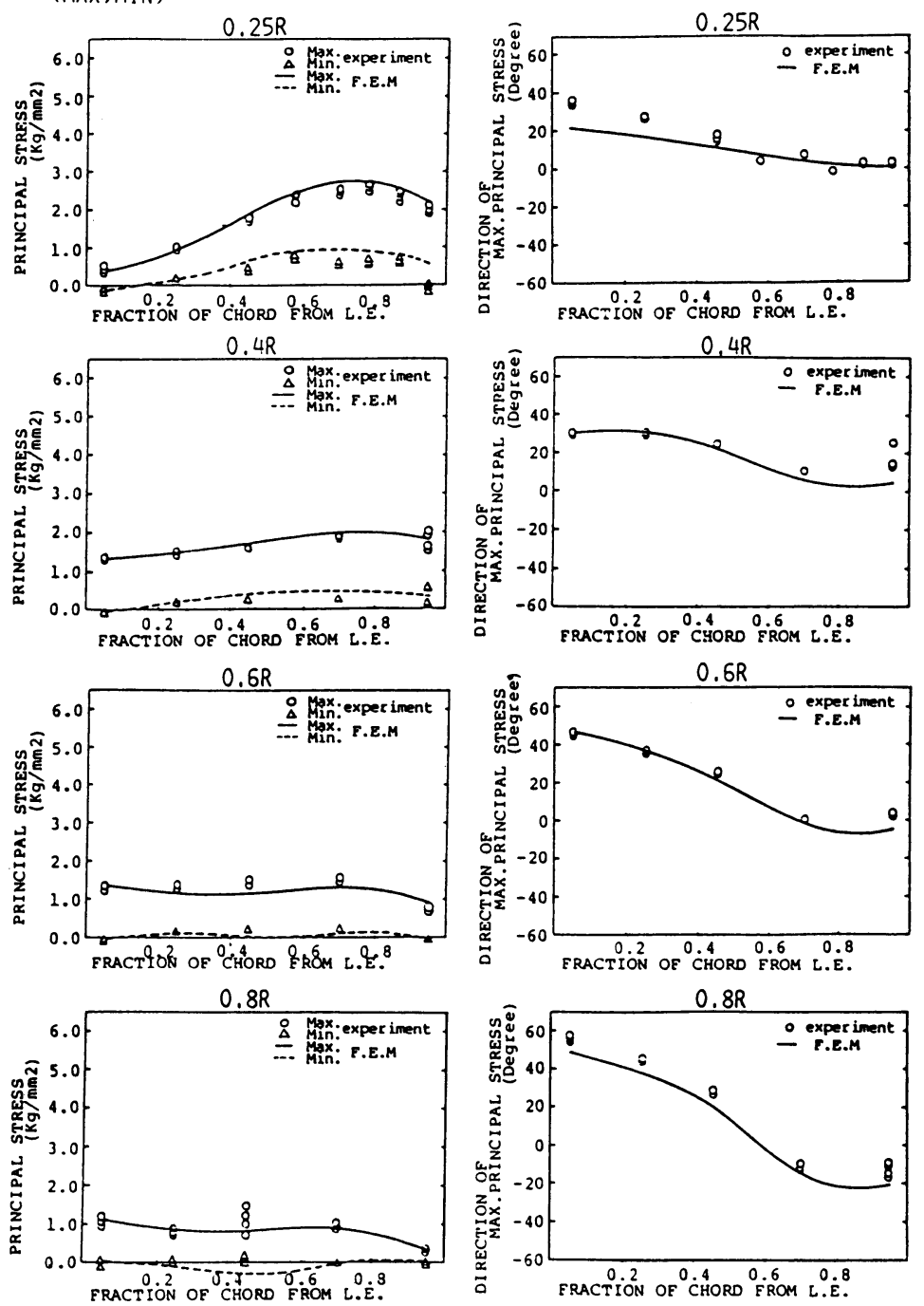

COMPARISON OF PRINCIPAL STRESS BETHEEN CALUCULATION AND EXPERIMENT

図A 1 静的試験における主応力值と FEM解析による主応力值の比較

の翼応力実測結果と理解しております.

先に発表されている神戸製鋼の論文ではプロペラ逆転 時に非常に大きな翼応力が発生すると発表されています. もし,よろしければプロペラ逆転時の今回の実船計測結 果をご教示戴きたく，よろしくお願い申し上げます.

[回答〕クラッシュ・アスターンを含めアスターン時
の翼応力計測も行いましたが, データの解析はまだ行っ ておりません.ただ，計測時に応力波形をモニターオッ シロにより観察した限りでは，で指摘のとおりかなり大 きな翼応力が発生していたてとは記憶しております．今 後, 解析が終了次第, その結果の発表の機会を得たい之 考えております. 